\title{
The future of the phenomenon 'Tradition' and the future of Museology as a scientific discipline
}

El futuro del fenómeno de la Tradición y el futuro de la Museología como una disciplina científica

Luciana Menezes de Carvalho

\section{OpenEdition}

\section{Journals}

Electronic version

URL: http://journals.openedition.org/iss/2043

DOI: $10.4000 /$ iss. 2043

ISSN: 2306-4161

Publisher

ICOM - International Council of Museums

Printed version

Date of publication: 1 August 2020

Number of pages: 109-120

ISBN: 978-2-491997-11-3

ISSN: 2309-1290

\section{Electronic reference}

Luciana Menezes de Carvalho, "The future of the phenomenon 'Tradition' and the future of Museology as a scientific discipline », ICOFOM Study Series [Online], 48-1 | 2020, Online since 01 August 2020, connection on 08 August 2020. URL : http://journals.openedition.org/iss/2043 ; DOI : https://doi.org/ $10.4000 /$ iss. 2043 


\section{The future of the phenomenon 'Tradition' and the future of

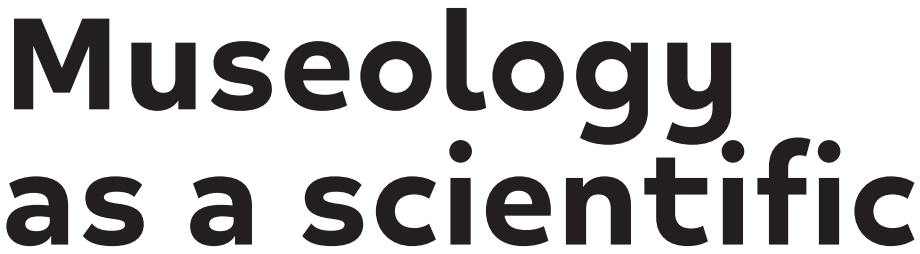 discipline}

\section{Luciana Menezes de Carvalho}

Museum of Memory and Heritage of the Federal University of Alfenas, Minas Gerais, Brazil

\section{A BSTRACT:}

In the proposal here presented, the first version of which was published in the "Materials for a discussion", I have organized the theme into three parts: the first discusses the concept of Tradition and contemporary authors that reflect about it; the second discusses some reflections about science, considering it as a tradition and using Bourdieu as reference, and discussing also some ideas about museum and Museology; and finally, the future of these both, considering the time that we are living and a problem that, I stress, needs to be faced: the post-truth phenomenon. 
Keywords: Museum, museology, science, tradition, heritage, posttruth.

RESUMEN:

\section{El futuro del fenómeno de la Tradición y el futuro de la Museología como una disciplina científica}

La propuesta aquí presentada, cuya primera versión ha sido publicada, en el libro "Materials for a discusion", ha sido organizada en trés partes para el tratamiento del tema. Una primera parte, en la que se analiza el concepto de Tradición a partir de autores contemporáneos que reflexionan sobre el tema; la segunda parte, donde se discuten algunas reflexiones sobre ciencia, entendiéndola como una tradición y teniendo a Bourdieu como referencia teórica, para también discutir algunas ideas sobre museo y Museología. Y finalmente, argüir sobre el futuro de todas esas instancias, considerando nuestra contemporaneidad y planteando un problema que destacaremos y que debemos enfrentar: el fenómeno de la post-verdad.

Palabras clave: Museo, museología, ciencia, tradición. patrimonio, Post-verdad.

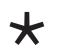

\section{Initial words:}

As the theme proposed by ICOFOM to be discussed in 2019 was "The Future of Tradition in Museology", we started to think at first about the future of the phenomenon "Tradition" itself, that in the $2 \mathrm{I}^{\mathrm{st}}$ century has had an important role in the cultural practices and the future of Museology as a scientific discipline. But it is this last case, without thinking of it isolated from the scientific field, which has been challenged nowadays.

Thence the present paper is divided as follows: I) a brief discussion about the concept of Tradition and its perspectives today; 2) a short presentation about the scientific field, its structure and its authority acquired in the 2oth century (also considering science as a tradition in Western society); and 3 ) the posttruth phenomenon which will put science at stake in the $2 \mathrm{I}^{\text {st }}$ century and how Museology and museums can deal with such confrontation. 


\section{About the Tradition phenomenon in the contemporary world: invention and remains}

Among the "historical things" that last, some of them receive the status of heritage, as Brulon Soares claims. Such happens when a collectivity decides to explicitly maintain or transmit them; or when these "historical things" refer to such a community, inserted in their "living memory" such that they might be recognized as inheritances (Brulon Soares, 2006) or traditions.

Hartog reminds us that the relationship with heritage and traditions does not take place in the past but in the present. Throughout the last hundred years we have been achieving the greatest and most important advancements in human history, and, as a paradox, we have been carrying out policies on heritage as a way to make up for our current life style. According to Gonçalves (2007), currently the emphasis applied to the category 'heritage' has been highlighting its 'built' or 'invented' aspect, which for this author is essential when we want to understand this category.

Nevertheless, every "heritage should not be studied from the past but rather from the present, as a category of action in the present and concerning the present" (Hartog, 2006, p. 270). It is relevant to say that we must be aware of the fact that we choose what we judge as important in the present, considering - or using an 'excuse' - that it will be important in the future. Eric Hobsbawm calls attention to this fact: "traditions' which appear or claim to be old are often quite recent in origin and sometimes invented" (I984, p.9). 'Invented' has a meaning related to production, creation - it is relevant to understand that traditions are dated, they have a delimited origin, they do not exist by themselves, they are not beyond humankind, they are made by humans themselves. Still citing Hobsbawm,

'Invented tradition' is taken to mean a set of practices, normally governed by overtly or tacitly accepted rules and of a ritual or symbolic nature, which seek to inculcate certain values and norms of behavior by repetition, which automatically implies continuity with the past. In fact, where possible, they normally attempt to establish continuity with a suitable historic past $(1984$, p. 9).

\section{9}

'Heritages', as I said before, can be seen as bridges between the past and the present; however we must consider that these bridges are built in the present and they do not take us precisely to the past, but to the representations - or the material properties - we have in the present that connect us to a possible past. Tradition, according to Silveira and Buendía, would be the impulse to "cross the bridge towards a new identity that seeks legitimacy with a certain past, projecting itself to the future" (20II, p. I60). 
Hobsbawm (I984) mentioned that invented traditions usually have invariance as a characteristic: "the past, real or invented, to which they refer to imposes fixed (normally formalized) practices". Social customs, on the other hand, cannot stop the innovations and are adaptable to social changes. This author also believes "'custom' cannot afford to be invariant, because even in 'traditional' societies life is not so" (1984, p. ro). Hobsbawm notes that it is part of any social practice "that needs to be carried out repeatedly [that it] will tend, for convenience and efficiency, to develop a set of such conventions and routines, which may be de facto or de jure formalized for the purposes of imparting the practice to new practitioners" ( 1984, p. II), even in society or community traditions.

Considering community as a social local group which is composed of a set of organized individuals, under a territorial base and interrelated to each other by a feeling of belonging and a sharing of common representations, values and meanings, it is important to consider that this local group is integrated into a huge and complex social structure, of a macrosocial character. Therefore, the knowledge, preservation, and valorization of heritage and traditions by such a community fundamentally contribute to the enhancement of its subjectivity and identity.

However, it is important to understand that, regarding heritage and traditions, there is a process of dispute for power, aiming at the selection and legitimation of heritages and traditions by institutional instances. These institutions are in charge of protectionist laws and preservation policies that, most of the time, contribute to an elitist and official version of heritage or tradition. Therefore, to understand the power relations in which communities are involved allows us to think about heritage and tradition, in a theoretical or practical way, as far as it is considered the macrosocial character that involves it and affects the building of a cultural identity. Thus, we can see the importance of local museum actions to empower traditions.

\section{About Science and the scientific field: trajectory and consolidation (and museums and Museology's role in this process)}

I will next analyze briefly how science was shaped and how it is shaped nowadays; how it built and established a tradition relying on what could be determined as true/veridical; and how the relationship with this tradition in post-truth contemporaneity is able to - and might well - affect museums and Museology.

What would move us to aspire to new scientific knowledge? The most important element, the one that guides us through all scientific practices, according to Bourdieu (1976, p. 3), would be the seeking of scientific authority. That means any interest in a certain activity - or in creating a new discipline, science or field - would have a double objective: the activity itself and the scientific authority it creates. The highest goal of a dispute in the scientific field, more 
than positions and classifications, would be the monopoly of acknowledgement that a certain point of view is legitimate, ignoring that it is "private, located and dated" (Bourdieu, 2013, p. 5I). Not only that: science and its actors have been creating and keeping mechanisms that maintain this reasoning since the separation of the scientific from the political and religious fields.

Thus, it is possible to infer that every epistemological conflict is also a political one. Bourdieu (1976) claims that "there is no 'scientific' choice" that is not a political strategy aiming to acquire a specific scientific capital that would be, in this case, the obtainment of peer recognition. The epistemological conflict that seeks the definition of science or what is scientific is always in fashion; that is, it is always on the debate among science actors because it is paramount in getting scientific recognition. Definitions created by certain actors focus on answering their own specific interest. In other words, seeking scientific authority and its productions is a capital whose clients are the competitors in the scientific field. Individuals who are not in this field or do not have any scientific know-how are not allowed to participate in it; it is not even possible to do so.

The scientific field's structure is defined by the dispute among its protagonists - agents or institutions that compete for the distribution of a specific capital. This structure is in the core of transformations occurring in the scientific field, whose tools are strategies of 'conservation or subversion' of this field's structure. Therefore, the transformations are products of their own conservation (Bourdieu, 1976). It is relevant to mention that the scientific field is not made up of individual agents only. There are institutions as well that not only participate in the field's disputes but also in the process of distribution and promotion of science's products or capitals, managed through the development of the scientific field. Bourdieu includes universities among these institutions, and in this paper I also include museums. They maintain the established scientific order and are charged with ensuring the production and circulation of scientific productions, producers and consumers. These last we can infer go beyond the scientific field: on behalf of what we know as 'scientific publicizing' we can find 'educational actions' (Bourdieu, 1976, p. 17), whose focus is to attract new people to the science field. In this process, museums have had a fundamental role since the i8th and igth centuries.

Bourdieu claims the dispute in the scientific field tends to intensify. There are more and more specialized areas dividing the competitors, increasing scientific resources and capital, raising the competition among parties to have the right to be part of the scientific field. However, it is necessary to relativize the autonomy of any field, including the academic and scientific: these fields produce the belief that their research goals (their productions) answer the field's internal demands instead of external demands. This is what Bourdieu (I976) calls "dependence on the appearance of independence". After all, the science field is one of the most dependent on the belief in its own power, whose 
symbolism produced by its own discourse is simultaneously appropriated by the group of producers (Bourdieu, I976, p. I2).

The hard way to walk - and understand - shows that it is only possible to contribute to science when we avoid using it as a resource of power, using its mechanisms (position, knowledge) to legitimate its own contributions. For those who are inside the scientific field, it is not possible to understand their analysis without understanding the logic behind science's line of thought. Scientific practice tends to become ordinary and its own activities can be executed without any reflection or critical control. Therefore, the criteria used to analyze and produce knowledge established by scientific fields (even those intending to be neutral) would be a result of the logics created by these fields. The hierarchies present in science fields are usually naturalized, which does not allow their members to acknowledge their own particular field as a powerful one.

Since the i8th century, museums, as spaces for sharing scientific knowledge, have been concerned about the manner in which they introduce themselves to the audience in a way that everybody is able to understand the content - even children (Burke, 2012, p. I23). Burke notes that it would be naive to think of museums as neutral human knowledge collections and ignore their own colonialist characteristics. Even the way the exhibits were disposed and organized showed how scientific thought was shaped in that moment. For example, Franz Boas proposed to the Smithsonian's curator to organize the exhibits of Amerindian artifacts by region, instead of organizing them under an evolutionist perspective (Burke, 20I2, p. I23-I24).

The rigth century was important in spreading western knowledge to the rest of the world, especially through central institutions such as universities, libraries and museums. These institutions were significant in reproducing a way to organize, produce and spread scientific knowledge - fruit of the western society. When it comes to museums, it was not only about scientific knowledge, but ways to live, organize and relate to societies, where their realities would be approached and reproduced within this realm. Nevertheless, it is important to remember that according to Burke (2012, p. I5) it was an 'active reception' where these groups took over this knowledge and adapted it to their realities. But the central role that museums had in the Igth century, including the scientific one mentioned above, was the participation in the process of building the idea of Nation. Institutions that had names suggesting some 'national pride' were created in their majority under the initiative of different governments, such as the Danish National Museum (I809), Prague's National Museum (I8ig), London's National Gallery, among many others (Burke, 20I2, p. 244). In that moment, museums reproduced and created a type of social representation that they wanted to highlight: the 'Nation' - an imagined community, as Anderson underlined - needed tools to reinforce and validate their importance. In this process, museums became stronger as institutions whose discourses were not only valid but also unquestionable, strengthening the idea of nation. This 
process was repeated along the trajectory of this social phenomenon called Museum in the zoth century.

However, we must remember that, according to Brulon Soares (20II), there is a need to evoke "the power of the Classics" to a Museum, that is, to trace a Museum's history that begins in Ancient Greece, in its most known story. This idea resembles the evolutionist attitude which creates a single common thread, especially to Europeans whose cradle of civilization is in Greece. In this point museum and culture converge as construction traditions, or as a result of a specific way to be in the world (Carvalho, 20I7).

Traditions, as Eric Hobsbawm demonstrated, in an influent way, are most of the time invented, individually or collectively, consciously or unconsciously, as a set of practices regulated by rules socially accepted (Brulon Soares, 2011, p. 46).

99

Museums had an important role in the consolidation of the scientific field. Many museum professionals since the igth century have been spreading and producing scientific knowledge in museums. For instance, the Smithsonian Institution, in the United States, not only works as a catalyst, but also as a producer of scientific knowledge. In Brazil, for example, the most prominent museums were the National Museum, Museu Paulista (São Paulo's Museum), Museum of Astronomy and related sciences, and Emilio Goeldi Museum, in Pará. These research institutes are real authorities in the science field due to their research, post-graduate programs, exhibitions and publications.

I reiterate, therefore, the idea that museums, over the trajectory here presented, developed a strategic role in the diffusion of a specific way of thought - the scientific one - that is hegemonic. Being an institution or a phenomenon, the museum has also participated in the consolidation of the scientific field: because of its unquestionable character of source/reference (the museum discourse is rarely put to the test), it has served as a diffuser and legitimative center of scientific knowledge.

\section{About the "post-truth" phenomenon: confrontations in the scientific field, museums and Museology}

Nowadays, the rupture with the idea of science and its disciplines as wielders of the "absolute truth" is beneficial to understand different ways to organize and comprehend the world and its different social groups. However, a contemporary phenomenon called "post-truth" has been causing turmoil in the scientific field.

I. This term was used by Brulon Soares (20II, p. 46). 
In a world with many significant information vehicles sharing many messages, one cannot evaluate the veracity of their own information in a safe systematic way. Silva, Luce and Silva Filho (2017) remind us that the current environment of uncertainties and insecurities caused by dichotomies of thought allow "specialists in distorted biased information" to spread their content without any regulation. Therefore, according to these authors, "the post-truth informational context" brought forth a third element: ambiguity because not everything could be considered a 'truth' or a 'lie'. This ambiance is characterized and intensified in a space/time where a lot of polarization of opinions is found, comprised of different groups with varied ideas and points of view; such ambiance is located majoritarily on "social media, finding space and audience in a very easy way to expand and gain strength" (Silvia, Luce and Silva Filho, 20I7, p. 284).

Another fact mentioned by Carvalho and Belda (2017) is the crisis in journalism - which during the zoth century focused on the notions of bias and neutrality, when it was supposed to "have accuracy in data verification and reliability as the profession's basic values" (Carvalho \& Belda, 2017, p. 235).

According to the discourse theory, there is an ideological determination that makes the individuals capable of defining gestures of expression as well as interpreting reality. There is not a single description without interpretation. Therefore, there is no objectivity or neutrality in journalism practices; these adjectives only suggest language effects. Therefore, the crisis in journalism and the emergence of what is called 'post-truth' can be seen as the moment when it is evident that it is impossible for unbiased narratives to exist in the press (Carvalho \& Belda, 2017, p. 237).

99

Silva, Luce and Silva Filho mention the elections in the United States as one example, in which a certain study followed over 40 published articles. Half of these articles came from traditional media vehicles and the other half came from blogs written by supporters and sympathizers which did not have any criteria for sharing reliable sources for their articles.

At the end of the research it was verified that the news that came from supporters' blogs produced 8.7 million sharings whereas news that came from communication vehicles had 7.3 million sharings on Facebook (2017, p. 276).

In a similar case in Brazil, 
[...] BuzzFeedNews applied the same procedures to analyze zo different news shared on Facebook on the Car Wash Operation, executed by the Brazilian Federal Police. They used as samples 10 articles from traditional Brazilian communication vehicles such as Folha de São Paulo, G1, Carta Capital, UOL and Época, and other 10 articles from blogs. The result was, just like in the United States, news written on blogs without defined origins or reliable sources had a larger number of sharings (over 3.870,066 sharings) than the articles produced by established communication vehicles (over 2.749,222 sharings) (2017, p. 276).

Regardless of how this situation in the United States or Brazil has been affecting elections or not, these are decisive moments for nations and group relations - especially the relations involving majority and minority groups. So, when it comes to science, what is even more alarming is the effect of certain beliefs in certain conjectures/paradigms that are 'false' (in comparison to what is considered as veridical information). This might affect what science has taken centuries to build methodologically: analysis, examination, confirmation of existing or constructed phenomena and formulated hypotheses. Science also built and consolidated the belief that results produced by its actors were veridical and legitimate. Through this methodology, the post-truth era exposes the frailty of science's most valuable product. However, Castells (2016) affirms that the posttruth is "[...] a social phenomenon that is too recent for the academic research to have an opportunity to come to solid conclusions about its social meaning".

How does this 'post-truth environment' affect or would affect Museology and museums?

Museology can be perceived as a group of knowledge comprising various forms of 'theorization or critical reflection on the museum field' (Desvallées \& Mairesse, 2013, p. 54). It would include all the other definitions of what Museology is ("museum studies", "New Museology", "critical Museology", "relationship between human and reality", "museum philosophy", among others). Museology has been claiming it is a protagonist of a specific and specialized knowledge on museums, creating analytical concepts to understand the social phenomenon Museum and its particularities, and also with an effort to indicate ways to many practices that exist in various museum models and manifestations.

Museum's shapes and functions have been changed over time, and that has happened because different communities or societies have claimed this social phenomenon. Although museums originally have been part of a society and social group type, nowadays distinct social groups and communities have possessed their own museums or have occupied the traditional ones: indigenous, LGBTQIA communities, immigrants, etc. After all, as Brulon Soares puts: "Museums create and change the social order as much they are created by 
it" (20I4, p.xxii). In other words, it is not just a one way interaction, where community/society interfere and build their museum; these instances are also affected and changed by their museums.

To be clear, in spite of museums having been recreating themselves in order to reach various communities' demands, such as the new technologies that ravage us nowadays, they still have a minimal ethical commitment to the 'truth' from the group to which they belong - western society, which is the museum's historical origin, or other groups, respecting the groups' differences, given harmony among all the different practices. Thus, the museum's tradition of changeability and its commitment within its own groups, including its original (and traditional) commitment to science and its challenges in face of the post-truth phenomenon, will be the greatest confrontation for museums in the $2 \mathrm{I}^{\mathrm{st}}$ century.

\section{Final thoughts:}

Carvalho and Belda present us another possible alternative to face the posttruth phenomenon:

Therefore, there are two aspects about the emerging of post-truth.

One refers to the inability of distinguishing the reports based on inventions, especially those aiming political disputes on social media. In this context, journalism must recreate itself in deontological and epistemological procedures in order to legitimate this place that it possessed in the 19th and 2oth century, that now it is going towards a different direction. Thus, initiatives such as those focused on mapping the reliability on journalism reports, and then establishing fact checking and verification criteria that are able to differentiate qualified information from rumors, fake news and other types of deceitful content which have been propagated on the chaotic environment of social media and networks in general (2017, p. 238).

We can also notice that it is not suitable anymore to think of a passive individual as a mere information receiver. The individual's beliefs and ideologies will lead them to rate, comment, share and (re)circulate selected information in an environment where it is possible to demonstrate whenever it is interesting to them (Carvalho \& Belda, 20I7, p. 238). In the journalism field what has been emerging, in contrast to the idea of neutrality/partiality, is believing in a possible multipartiality, suggesting "a plural perspective based on tolerance and empathy, but still committed to true information" (Carvalho and Belda, 20I7, p. 240). 
The notion of multipartiality as a plural approach that overcomes the neutrality paradigm in mediation processes, [and] has traditions which are parallel to law, social education, psychoanalysis and management studies, especially on intergroup dialogue, negotiation and conflict solution. The definition of this term varies according to the context, including the idea of a mediator that takes the side not in favor of a single party (partiality) or none of the parties (impartiality) - but takes side on multiple parties, on a larger picture, a dialogue that aims at balancing the multiple voices or identities involved in the interlocution, with the objective of equalizing the potentialities of representation (Carvalho \& Belda, 2017, p. 239).

Therefore, museums would have the effort to gather different perspectives about any theme, whether these pespectives are scientific or not, equalizing them; but also the responsibility to denounce the discourses which would be able to damage or minimalize any other narrative (including the scientific one) or even conduct mistakes which might injure human rights.

However, even Science or any other way of knowledge is at the service of its Creator: and this creator is not a divine being, but a total human being. But he/she is not unique; he/she is constituted as a collectivity: the social body. Human beings, in diversity, create unity - of thoughts, fields, disciplines, and ideas - unities that are going to unfold infinitely. Museology and its different nomenclatures and streams - New Museology, Museum Studies, Museum Philosophy - is a result of a process that happens when an actor or group claims its space. The same thing happens with all kinds of knowledge, theories, ideas, or even "fake news": because all of these thoughts want to be recognized. Recognition would be the main reason and objective of Science and its countless theses; but it would also be the main reason and objective of our own human existence, for the "divine" (or "human") right of existence and coexistence (Carvalho, 20I7).

\section{References}

Bourdieu, P. (2013). A distinção: crítica social do julgamento. Porto Alegre, Rio Grande do Sul: Zouk.

Bourdieu, P. (1976). O Campo Cientifico. Retrieved from http://uaiinformatica. net/luciana/campo_cientifico_bourdieu.pdf.

Brulon Soares, B. (2006). Em busca do tesouro perdido: a Nova Museologia, o Novo Museu e a América Latina. Master Thesis (Mestrado em Museologia e 
Patrimônio), Programa de Pós-Graduação em Museologia e Patrimônio, Unirio/MAST.

Brulon Soares, B. (20II). O rapto das Musas: apropriação do mundo clássico na invenção dos museus. Anais do Museu Histórico Nacional, Rio de Janeiro, 43, 4I-65.

Brulon Soares, B. (2014). As coleções de museus criam conexões: percursos da musealização no Musée du Quai Branly. Anais da VI Semana Nacional de Museus na UNIFAL-MG, V, xxii-xxxvi.

Burke, P. (2012). Uma história social do conhecimento. Da Enciclopédia à Wikipédia. Rio de Janeiro: Jorge Zahar Editor.

Carvalho, L. M. (20I7). Do museu a museologia: constituição e consolidação de uma disciplina. PhD Thesis (Doutorado em Museologia e Patrimônio), Programa de Pós- Graduação em Museologia e Patrimônio, Unirio/ MAST.

Carvalho, P. H. V., \& Belda, F. R. (20I7). Multiparcialidade, dialogia e cultura participativa como reação à pós-verdade: uma abordagem discursiva sobre o jornalismo. Culturas Midiáticas, I8, 230-245.

Castells, M. (2016). A sociedade em rede. São Paulo: Paz \& Terra, I7.

Desvallées, A., \& Mairesse, F. (Eds.). (2013). Conceitos-chave de museologia. ICOM, ICOM-BR: Pinacoteca do Estado de São Paulo.

Gonçalves, J. R. S. (2007). Antropologia dos Objetos: Coleções, Museus e Patrimônios. Coleção Museu, Memória e Cidadania: Rio de Janeiro.

Hobsbawm, E. (1984). A invenção das tradições. Rio de Janeiro: Paz e Terra.

Hartog, F. (2006). Tempo e Patrimônio. Varia Historia (p. 26I-273). Belo Horizonte: v. 22, n. 36 .

Silva, L. M., Luce, B., \& Silva Filho, R. da C (2017). Impacto da Pós-Verdade em Fontes de Informação para a Saúde. XXVII Congresso Brasileiro de Biblioteconomia, Documentação e Ciência da Informação / Revista Brasileira de Biblioteconomia e Documentação, I3, 27I-287.

Silveira, L. B., \& Buendía, M. P. (20II). Da invenção da tradição (ou como os patrimônios nos inventam). Notas sobre a patrimonialização do pastoreio na Espanha. Horizontes Antropológicos, Porto Alegre, 36, I45-I69. 